\title{
Highly Efficient Synthesis of Licochalcone E through Water-Accelerated [3,3]-Sigmatropic Rearrangement of Allyl Aryl Ether
}

\author{
Jae-Ho Jeon, Mi Ran Kim, ${ }^{\dagger}$ Eun Mi Kwon, ${ }^{\dagger}$ Na Ri Lee, ${ }^{\dagger}$ and Jong-Gab Jun ${ }^{\dagger, *}$ \\ Institute of Natural Medicine, 'Department of Chemistry and Institute of Applied Chemistry, Hallym University, \\ Chuncheon 200-702,Korea.*E-mail: jgjun@hallym.ac.kr \\ Received November 23, 2010, Accepted January 4, 2011
}

Key Words : Licochalcone E, Claisen-Schmidt condensation, Water-accelerated [3,3]-sigmatropic rearrangement, Claisen rearrangement, Co-solvent system

Retrochalcones (licochalcones A-E, echinatin) were isolated and characterized from the roots of oriental herb, $G$. inflata. ${ }^{1}$ They are reported to have various biological activities; antitumor, ${ }^{2}$ anti-inflammatory, ${ }^{3}$ vascular, ${ }^{4}$ cytotoxic, ${ }^{5}$ anti-proliferative, ${ }^{6}$ inhibitor of topoisomerase $\mathrm{I}^{7}$ protein tyrosinase phosphatase $1 \mathrm{~B}^{8}$ etc. Among these, licochalcone E (Fig. 1) gets drawing attentions due to its promising biological activities (antitumor, ${ }^{9}$ vasorelaxant, ${ }^{4}$ anti-inflammatory, ${ }^{3}$ cytotoxic, ${ }^{3}$ inhibitor of topoisomerase $\mathrm{I},{ }^{4}$ protein tyrosine phosphatase $1 \mathrm{~B}^{4}$ etc). But because of the low isolated yield ( $5 \mathrm{mg}$ from $1 \mathrm{Kg}$ dried $\mathrm{G}$. inflata $)^{7}$ and low yield producing current multi-step synthesis, growing needs were generated for developing new synthetic route.

Several syntheses of licochalcone E (4) were reported. Cheon et al. reported the first enantioselective total synthesis of this natural product, ${ }^{10}$ and also determined the absolute configuration of the asymmetric center of $\mathrm{C}_{1}$ " carbon. But their synthesis was so long that it looks tedious (21 steps, overall 5\% yield). Recently, Chinese group reported ${ }^{11}$ total synthesis of this molecule via abnormal induced Claisen rearrangement reaction ${ }^{12}$ as a key step (Scheme 1). It is well known that the Claisen rearrangement of allyl ethers which have $\gamma$-alkyl substituent is often complicated by the occurrence of abnormal rearrangement ${ }^{12}$ leading to structural isomerization of the migrating group. They exploited this phenomenon starting from 4-hydroxy-2-methoxybenzaldehyde (1). Allylation (86\%) at the 4-position of the phenyl ring followed by abnormal Claisen rearrangement reaction $(32 \%)$ in $\mathrm{N}, \mathrm{N}$-dimethylaniline (DMA), ${ }^{12}$ and ClaisenSchmidt condensation $(72 \%)^{13}$ in acidic condition completed this synthesis (3 steps, overall 20\%). Although their synthesis was breakthrough of current low yield producing multi-step synthesis, still the yield of the crucial step is bottleneck.

Related semi-synthesis through this abnormal Claisen rearrangement reaction was reported by Cheon's research

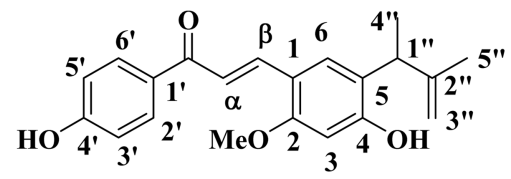

Figure 1. Structure of Licochalcone E. team (Scheme 2). ${ }^{4}$ They converted licochalcone A (5) to licochalcone E (4) with a good yield $(77 \%$ by thermal reaction). But this method has also limitation (valuable licochalcone A itself was used as a starting material).

Another important synthesis was done by Na's group

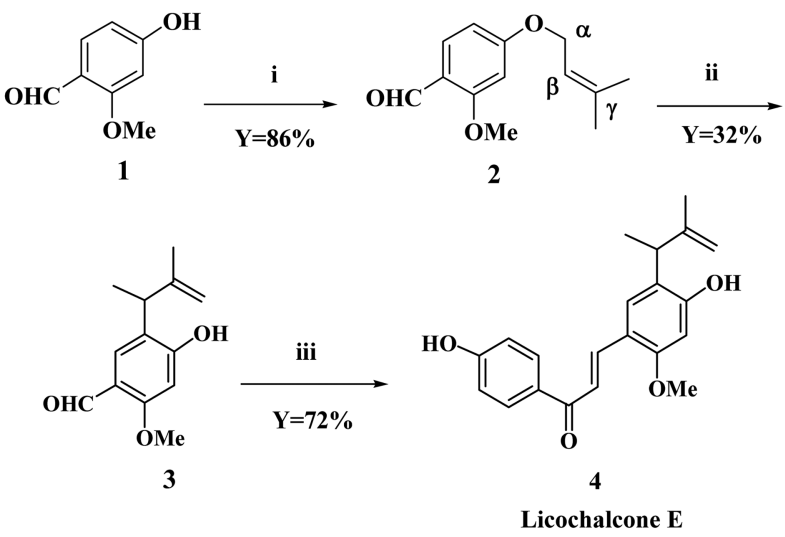

Scheme 1. Reagents and conditions; i) prenyl bromide (1.2 equiv.), $\mathrm{K}_{2} \mathrm{CO}_{3}$ (1.5 equiv.), acetone, rt, $24 \mathrm{~h}$, ii) $N, N$-dimethylaniline, sealed tube, $185^{\circ} \mathrm{C}, 26 \mathrm{~h}$, iii) 4-hydroxyacetophenone, $\mathrm{HCl}, \mathrm{EtOH}$, $0-5{ }^{\circ} \mathrm{C}, 2 \mathrm{~h}$.
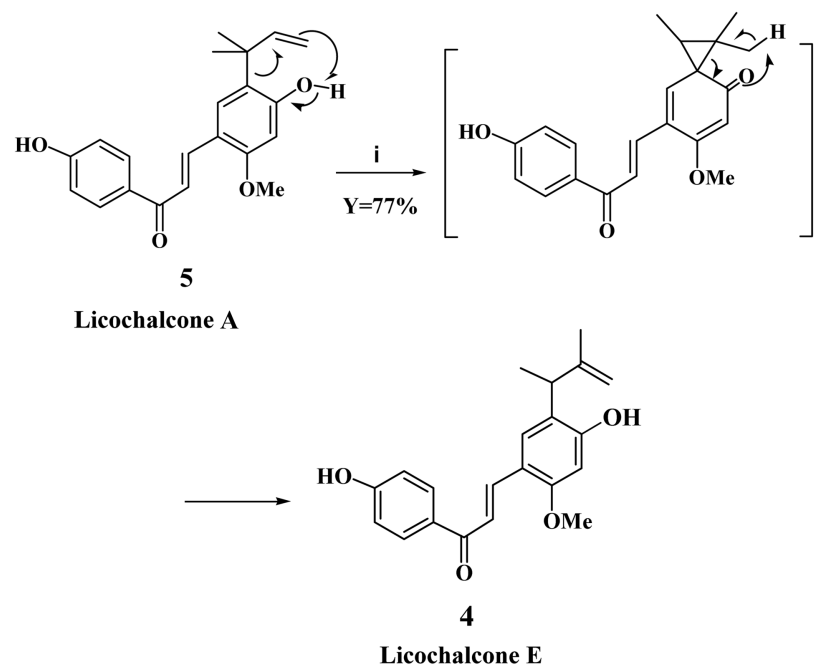

Scheme 2. Reagents and conditions; i) $N, N$-diethylaniline, $217^{\circ} \mathrm{C}$, $0.5 \mathrm{~h}$. 


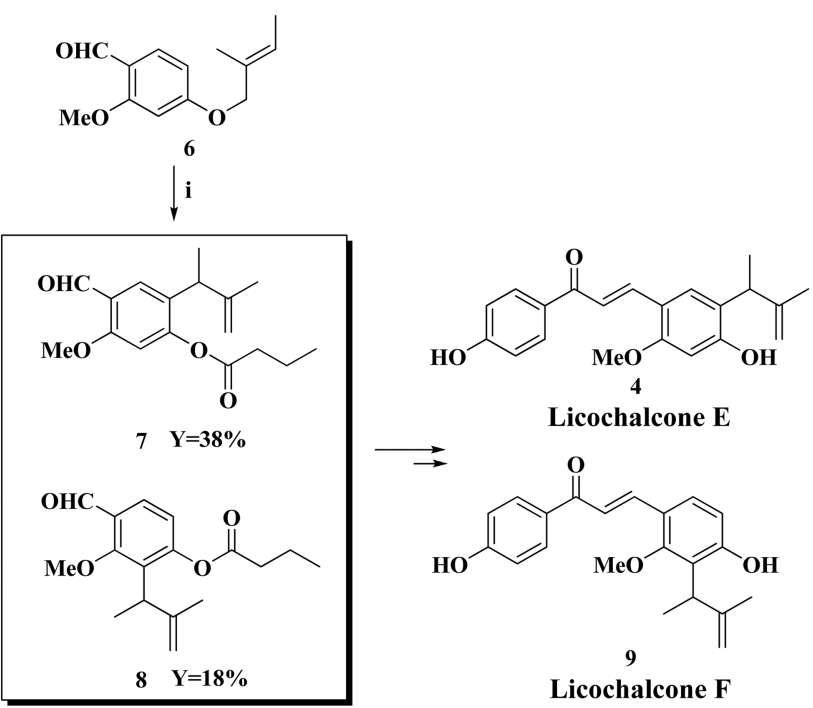

Scheme 3. Reagents and conditions; i) $n$-butyric anhydride, $N, N$ dimethylaniline, $220-240{ }^{\circ} \mathrm{C}, 3 \mathrm{~h}$.

(Scheme 3). ${ }^{14}[3,3]$-Sigmatropic rearrangement reaction in $\mathrm{N}, \mathrm{N}$-dimethylaniline with excessive butyric anhydride at 220-240 ${ }^{\circ} \mathrm{C}$ for $3 \mathrm{~h}$ produced the allyl group migrated products 7 and $\mathbf{8}$ in $38 \%$ and $18 \%$ yield, respectively. These were converted to licochalcone $\mathrm{E} \& \mathrm{~F}$ by series of reactions. The chemical yield of this rearrangement step was so low that definitely it needs to be much improved. Similar procedure, but [3,3]-sigmatropic rearrangement was carried out at the final stage was also reported. ${ }^{15}$ The yield, however, was very low (their best yield was $21 \%$ ). Recently, our research interest is focused how to supply of these important retrochalcones (especially licochalcone A \& E) for in vitro and in vivo studies in small laboratory animals and human cancer cell lines. As part of the efforts to improve the current synthesis of these important natural products, we had focused the existing water-accelerated organic reactions because water is known to enhance the reaction rates as well as to affect the selectivity of various organic reactions. Organic co-solvent system has been used not only to increase the solubility of organic reactions in water but also to speed-up certain kinds of reactions, ${ }^{16}$ Diels-Alder, ${ }^{17} 1,3-$ dipolar cycloadditions, ${ }^{18}$ cycloadditions of azodicarboxyl-

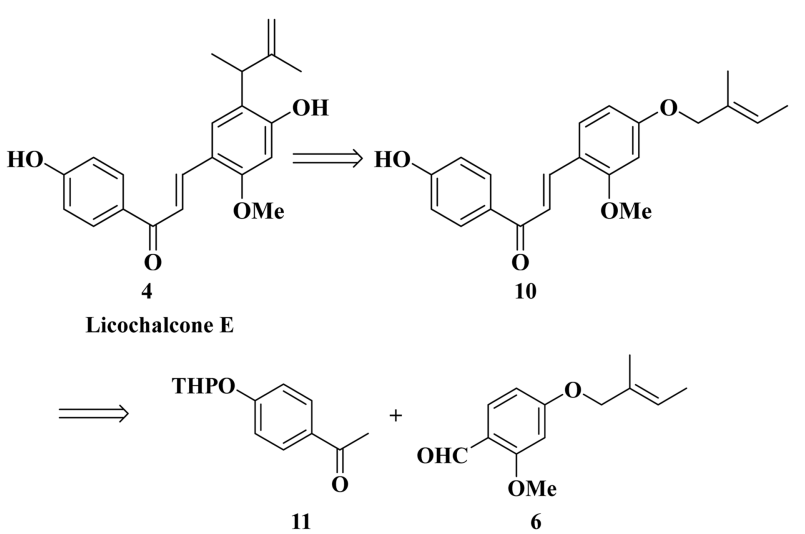

Scheme 4. Retrosynthetic analysis of licochalcone E. ates, ${ }^{19}[3,3]$-sigmatropic rearrangement, ${ }^{20}$ Passerni and Ugi reactions, ${ }^{21}$ nucleophilic substitution reactions, ${ }^{22}$ waterSonogashira reactions, ${ }^{23}$ acqueous Suzuki-Miyaura reactions. $^{24}$

We recently developed $\mathrm{EtOH} /$ water co-solvent system to speed-up the [3,3]-sigmatropic rearrangement reaction using either microwave or sealed tube for the synthesis of licochalcone $\mathrm{A} \mathrm{(5)}{ }^{25}$ As the current low isolation yield, in vivo studies of licochalcone $\mathrm{E}$ (4) have been severely limited. Therefore, significant growing need was generated for developing effective synthetic methods in preparing this important natural product. We thought that we can convert chalcone compound (10) to licochalcone E through [3,3]sigmatropic rearrangement using EtOH/water co-solvent system. Compound (10) can be prepared from ClaisenSchmidt condensation of THP-protected ketone (11) with aldehyde (6) (Scheme 4).

From readily available 4-hydroxy-2-methoxybenzaldehyde (1), the key intermediate (10) was prepared by 3 steps (Scheme 5). Allyation (93\%) at 4-position with (E)-2methyl-2-butenyl bromide (12) followed by ClaisenSchmidt condensation (71\%) with compound (11) produced THP-protected chalcone aryl ether (13). Deprotection of THP group under mild acidic condition produced the chalcone aryl ether (10) in $83 \%$ yield.

Then, conversion of $\mathbf{1 0}$ to licochalcone E (4) was intensively studied (Scheme 6, Table 1). The [3,3]-sigmatropic rearrangement reaction was carried out in the stainless steel bomb reactor with $\mathrm{EtOH} /$ water co-solvent system. At 130 ${ }^{\circ} \mathrm{C}$, the reaction proceeded with moderate yield for $24 \mathrm{~h}$ (67\%; entry 1 ) to give licochalcone E, but decomposition of the product was observed in the longer reaction time (entries 2-3). The reaction did not proceed at all at $150{ }^{\circ} \mathrm{C}$ for $12 \mathrm{~h}$ (entry 4), but gave the best [3,3]-sigmatropic rearrangement yield at $150{ }^{\circ} \mathrm{C}$ for $24 \mathrm{~h}(84 \%$; entry 5$)$. The loss of allyl group was observed at $180{ }^{\circ} \mathrm{C}$ due to harsher reaction condition (entry 6). Loss of similar prenyl group of aryl prenyl ether in the [3,3]-sigmatropic rearrangement reaction was reported and this is one of the well known phenomena. ${ }^{26}$ However, Our water-accelerated [3,3]-sigmatropic rearrangement conditions using EtOH/water co-solvent system

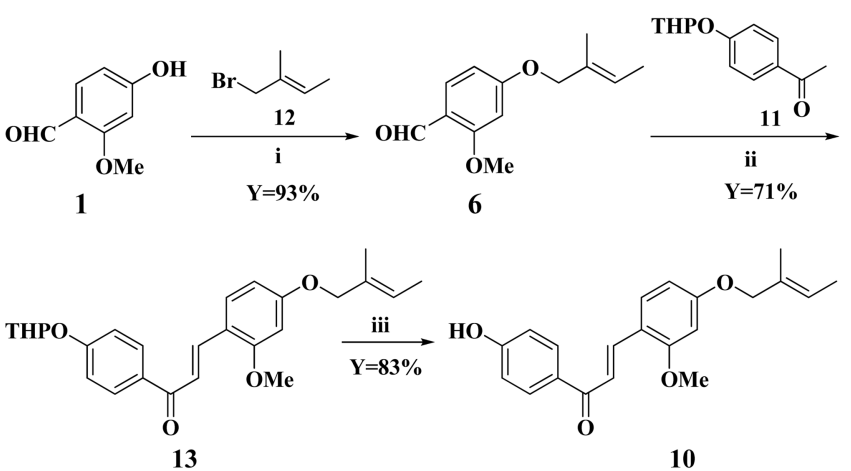

Scheme 5. Reagents and conditions; i) 12 (1.5 equiv.), $\mathrm{K}_{2} \mathrm{CO}_{3}(2.0$ equiv.), acetone, reflux, $3 \mathrm{~h}$, ii) $\mathbf{1 1}$ (1.2 equiv.), $\mathrm{KOH}$ (3.0 equiv.), $\mathrm{MeOH}, \mathrm{rt}, 12 \mathrm{~h}$, iii) EtOH, $1 \mathrm{~N} \mathrm{HCl}, 40^{\circ} \mathrm{C}, 1 \mathrm{~h}$. 


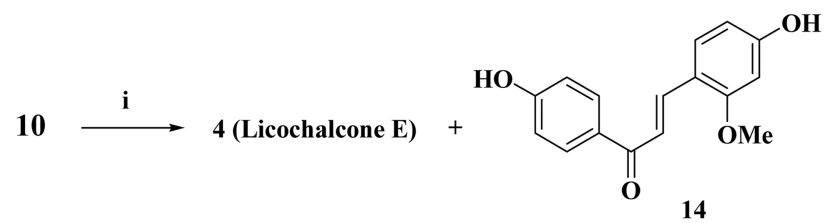

Scheme 6. Reagents and conditions; i) EtOH/water (4/1, v/v) cosolvent system.

Table 1. [3,3]-Sigmatropic rearrangement reaction of $\mathbf{1 0}$

\begin{tabular}{ccccc}
\hline Entry & Temp $\left({ }^{\circ} \mathrm{C}\right)$ & Time $(\mathrm{h})$ & Ratio $^{b}(4 / 14)$ & Yield $(\%)^{b}$ \\
\hline $1^{a}$ & 130 & 24 & $100 / 0$ & 67 \\
$2^{a}$ & 130 & 30 & $100 / 0$ & 50 \\
$3^{a}$ & 130 & 32 & $100 / 0$ & 50 \\
$4^{a}$ & 150 & 12 & - & - \\
$5^{a}$ & 150 & 24 & $100 / 0$ & 84 \\
$6^{a}$ & 180 & 24 & $50 / 50$ & 30 \\
\hline
\end{tabular}

${ }^{a}$ Reactions are carried out in the stainless steel bomb reactor. Electric furnace was used as a heating device. ${ }^{b}$ Silica gel column purified yield.

provided the best yield of licochalcone $\mathrm{E}$ without deallylated by-product or regio-isomer within $24 \mathrm{~h}$ at $150{ }^{\circ} \mathrm{C}$. The spectral data of licochalcone $\mathrm{E}$ were nicely matched to the previously reported results. ${ }^{4,10,11,14,15}$

In summary, we developed a new synthetic pathway which enables sufficient supply of licochalcone $\mathrm{E}$ for biological tests (4 steps, overall $46 \%$ yield). This method could overcome the current situation of depending on multistep synthesis due to low isolated yield from natural resources.

\section{Experimental Section}

All chemicals were purchased from Sigma-Aldrich Chemicals and were used without further purification unless noted otherwise. NMR spectra were recorded at Varian Mercury-300 MHz FT-NMR and $75 \mathrm{MHz}$ for ${ }^{13} \mathrm{C}$, with the chemical shift $(\delta)$ reported in parts per million (ppm) relative to TMS and the coupling constants $(J)$ quoted in $\mathrm{Hz}$. $\mathrm{CDCl}_{3}$ was used as a solvent and an internal standard. Thin-layer chromatography (TLC) was performed on DC-Plastikfolien $60, \mathrm{~F}_{254}$ (Merck, layer thickness $0.2 \mathrm{~mm}$ ) plastic-backed silica gel plates and visualized by UV light $(254 \mathrm{~nm})$ or staining with $p$-anisaldehyde.

(E)-3-[4-Hydroxy-2-methoxy-5-(3-methylbut-3-en-2-yl)phenyl]-1-(4-hydroxyphenyl) prop-2-en-1-one, Licochalcone E (4); General Procedure of water-accelerated [3,3]sigmatropic rearrangement of aryl allyl ether. $(E)-3-[2-$ Methoxy-4-(2-methylbut-2-enyloxy)phenyl]-1-(4-tetrahydropyranyl)prop-2-en-1-one, (10) (19 $\mathrm{mg}, 0.056 \mathrm{mmol})$ was dissolved in EtOH/water (4/1, v/v) $(3 \mathrm{~mL})$ and placed in a stainless steel bomb reactor. The bomb was tightly closed and put into inside of the electric-furnace operated at $150{ }^{\circ} \mathrm{C}$ for $24 \mathrm{~h}$. After cooling down to $\mathrm{rt}$, the bomb reactor was opened and the whole reaction mixture was transferred to $100 \mathrm{~mL}$ one neck round bottom flask and the solvent was evaporated in vacuo. Ethyl acetate $(50 \mathrm{~mL})$ was added and the organic phase was washed with distilled water $(20 \mathrm{~mL})$ and brine $(10 \mathrm{~mL})$. The organic phase was dried over anhydrous $\mathrm{MgSO}_{4}$ and filtered. The solvent was evaporated in vacuo. The residue was purified by silica gel flash column chromatography (EtOAc-Hexane $=1: 10)$ to give an amorphous orange solid; yield: $16 \mathrm{mg}(84 \%)$. The spectral data of this compound was nicely matched to the literature value. ${ }^{4,10,11,14,15} R_{f}=0.41$ (EtOAc-Hexane $=1: 5$ ). ${ }^{1} \mathrm{H}$ NMR (300 MHz, acetone- $\left.d_{6}\right) \delta 8.00(\mathrm{~d}, J=15.9 \mathrm{~Hz}, 1 \mathrm{H}, \mathrm{H}-\beta)$, 7.97 (d, $J=8.7 \mathrm{~Hz}, 2 \mathrm{H}), 7.64$ (d, $J=15.6 \mathrm{~Hz}, 1 \mathrm{H}, \mathrm{H}-\alpha), 7.51$ (s, 1H), 6.94 (d, $J=8.1 \mathrm{~Hz}, 2 \mathrm{H}), 6.60(\mathrm{~s}, 1 \mathrm{H}), 4.89$ (d, $J=6$ $\mathrm{Hz}, 1 \mathrm{H}), 3.88(\mathrm{~s}, 3 \mathrm{H}), 3.81(\mathrm{~m}, 1 \mathrm{H}), 1.68(\mathrm{~s}, 3 \mathrm{H}), 1.36(\mathrm{~d}, J=$ $6.9 \mathrm{~Hz}, 3 \mathrm{H}) ;{ }^{13} \mathrm{C}$ NMR $\left(75 \mathrm{MHz}\right.$, acetone- $\left.d_{6}\right) \delta 187.6(\mathrm{C}=\mathrm{O})$, $161.5\left(\mathrm{C}_{4}^{\prime}\right), 158.8\left(\mathrm{C}_{4}\right), 158.5\left(\mathrm{C}_{2}\right), 149.1\left(\mathrm{C}_{2}{ }^{\prime \prime}\right), 139.1\left(\mathrm{C}_{\beta}\right)$, $130.8\left(\mathrm{C}_{2}{ }^{\prime}\right), 128.6\left(\mathrm{C}_{1}{ }^{\prime}\right), 128.6\left(\mathrm{C}_{6}\right), 124.2\left(\mathrm{C}_{5}\right), 118.8\left(\mathrm{C}_{\alpha}\right)$, $115.8\left(\mathrm{C}_{1}\right), 115.3\left(\mathrm{C}_{3}^{\prime}\right), 109.4\left(\mathrm{C}^{\prime}\right)$ ), 99.0 (C3), 55.4 (OMe), $38.1\left(\mathrm{C}_{1}{ }^{\prime}\right), 21.7\left(\mathrm{C}_{5}^{\prime \prime}\right), 19.0$ ( $\left.\mathrm{C}_{4}{ }^{\prime \prime}\right)$.

(E)-2-Methoxy-4-(2-methylbut-2-enyloxy)benzaldehyde (6). 4-Hydroxy-2-methoxybenzaldehyde (1) $(50 \mathrm{mg}, 0.33$ mmol), (E)-2-methyl-2-butenyl bromide (12) (74 mg, 0.49 mmol), anhydrous $\mathrm{K}_{2} \mathrm{CO}_{3}(91 \mathrm{mg}, 0.39 \mathrm{mmol})$ were dissolved in acetone $(10 \mathrm{~mL})$ and refluxed for $3 \mathrm{~h}$. After completion of the reaction, $\mathrm{K}_{2} \mathrm{CO}_{3}$ was filtered and the resulting solution was concentrated in vacuo and the residue was purified by silica gel flash column chromatography $($ EtOAc-Hexane $=1: 7)$ to give an oil; yield: $67 \mathrm{mg}(93 \%)$. The spectral data of this titled compound was nicely matched to the literature value. ${ }^{15} \mathrm{R}_{f}=0.30$ (EtOAc-Hexane $=1: 3)$.

(E)-3-[2-Methoxy-4-(2-methylbut-2-enyloxy)phenyl]-1[4-(tetrahydropyranyloxy) phenyl]prop-2-en-1-one (13). (E)-2-Methoxy-4-(2-methylbut-2-enyloxy)benzaldehyde (6) (170 mg, $0.77 \mathrm{mmol}$ ) and 4-tetrahydropyranyl acetophenone (11) $(217 \mathrm{mg}, 0.93 \mathrm{mmol})$ were dissolved in $\mathrm{MeOH}(5 \mathrm{~mL})$ at rt. Powdered $\mathrm{KOH}(130 \mathrm{mg}, 2.32 \mathrm{mmol})$ was added and reacted for $12 \mathrm{~h}$. After completion of reaction, $\mathrm{MeOH}$ was concentrated in vacuo and the whole reaction mixture was transferred into separatory funnel. Ethyl acetate $(30 \mathrm{~mL})$ was added and washed with distilled water $(20 \mathrm{~mL})$ and brine $(10$ $\mathrm{mL}$ ). The organic phase was separated, dried over anhydrous $\mathrm{MgSO}_{4}$ and filtered. The solvent was evaporated again and the residue was purified by silica gel flash column chromatography (EtOAc-Hexane $=1: 9)$ to give the titled compound as an oil; yield: $232 \mathrm{mg}(71 \%)$. The spectral data of this titled compound was nicely matched to the literature value. ${ }^{15} R_{f}=0.29$ (EtOAc-Hexane $=1: 6$ ).

(E)-3-[2-Methoxy-4-(2-methylbut-2-enyloxy)phenyl]-1(4-hydroxyphenyl)prop-2-en-1-one (10). In an one neck round bottom flask, (E)-3-[2-methoxy-4-(2-methylbut-2enyloxy)phenyl]-1-[4-(tetrahydropyranyloxy)-phenyl]prop2-en-1-one (13) (232 mg, $0.55 \mathrm{mmol})$ was dissolved in $5 \mathrm{~mL}$ EtOH. 2-3 drops of aqueous $1 \mathrm{~N} \mathrm{HCl}$ was added and stirred for $1 \mathrm{~h}$ at $40{ }^{\circ} \mathrm{C}$. After completion of the reaction, few drops of aqueous sodium bicarbonate solution were added to quench the reaction. The solvent was concentrated in vacuo and the whole reaction mixture was transferred into 
separatory funnel. Ethyl acetate $(50 \mathrm{~mL})$ was added and washed with distilled water $(20 \mathrm{~mL})$ and brine $(10 \mathrm{~mL})$. The organic phase was separated, dried over anhydrous $\mathrm{MgSO}_{4}$ and filtered. The solvent was evaporated again and the residue was purified by silica gel flash column chromatography (EtOAc-Hexane $=1: 5)$ to give the titled compound as an oil; yield: $154 \mathrm{mg}(83 \%) . R_{f}=0.27$ (EtOAc-Hexane $=$ 1:1). ${ }^{1} \mathrm{H}$ NMR $\left(300 \mathrm{MHz}, \mathrm{CDCl}_{3}\right) \delta 8.04(\mathrm{~d}, J=15.6 \mathrm{~Hz}$, $1 \mathrm{H}, \mathrm{H}-\beta), 7.95$ (d, $J=8.7 \mathrm{~Hz}, 2 \mathrm{H}), 7.54$ (d, $J=15.6 \mathrm{~Hz}, 1 \mathrm{H}$, $\mathrm{H}-\alpha), 7.51(\mathrm{~d}, J=8.7 \mathrm{~Hz}, 1 \mathrm{H}), 6.93(\mathrm{~d}, J=8.7 \mathrm{~Hz}, 2 \mathrm{H}), 6.52$ $(\mathrm{m}, 2 \mathrm{H}), 4.41(\mathrm{~s}, 1 \mathrm{H}), 3.85(\mathrm{~s}, 3 \mathrm{H}), 1.81(\mathrm{~s}, 1 \mathrm{H}), 1.74(\mathrm{~s}, 2 \mathrm{H})$, $1.68(\mathrm{q}, J=6.6 \mathrm{~Hz}, 2 \mathrm{H}), 1.25(\mathrm{~s}, 3 \mathrm{H}) ;{ }^{13} \mathrm{C}$ NMR $(75 \mathrm{MHz}$, $\left.\mathrm{CDCl}_{3}\right) \delta 190.5,162.6,160.8,160.5,140.6,131.8,131.3$, $131.2,124.8,120.2,117.3,115.8,106.5,99.4,74.6,55.8$, $30.1,14.1,13.8$.

Acknowledgments. This research was financially supported by the Ministry of Knowledge Economy through the Center for Efficacy Assessment and Development of Functional Foods and Drugs at Hallym University (B0008864), and by Priority Research Centers Program through the National Research Foundation of Korea (NRF) funded by the Ministry of Education, Science and Technology (20100029642).

\section{References and Notes}

1. (a) Saitoh, T.; Shibata, S. Tetrahedron Lett. 1975, 16, 4461. (b) Kajiyama, K.; Demizu, S.; Hiraga, Y.; Kinoshita, K.; Koyama, K.; Takahashi, K.; Tamura, Y.; Okada, K.; Kinoshita, T. Phytochemistry 1992, 31, 3229. (c) Yoon, G.; Jung, Y. D.; Cheon, S. H. Chem. Pharm. Bull. 2005, 53, 694 .

2. Kim, J. K.; Shin, E. K.; Park, J. H.; Kim, Y. H.; Yoon Park, J. H. J. Mol. Med. 2010, 88, 829.

3. Cho, Y.-C.; Lee, S. H.; Yoon, G.; Kim, H.-S.; Na, J. Y.; Choi, H. J.; Cho, C.-W.; Cheon, S. H.; Kang, B. Y. Int. Immunopharmacol.
2010, 10,1119

4. Yoon, G.; Oak, M.-H.; Lee, J.-O.; Cheon, S. H. Bull. Korean Chem. Soc. 2010, 31, 1085

5. Funakoshi-Tago, M.; Tago, K.; Nishizawa, C.; Tkahashi, K.; Mashino, T.; Iwata, S.; Inoue, H.; Sonda, Y.; Kasahara, T. Biochem. Pharmacol. 2008, 6, 1681.

6. Park, J.-H.; Lim, H. J.; Lee, K.-S.; Lee, S.; Kwak, H.-J. Biol. Pharm. Bull. 2008, 31, 1996.

7. Sato, T.; Inoue, H.; Shibata, S. J. Pharmacy and Pharmacology 2005, 57, 1661 .

8. Yoon, G.; Lee, W.; Kim, S. N.; Cheon, S. H. Bioorg. Med. Chem. Lett. 2009, 19, 5155.

9. Yoon, G.; Jung, Y. D.; Cheon, S. H. Chem. Pharm. Bull. 2005, 53, 694.

10. Liu, Z.; Yoon, G.; Cheon, S. H. Tetrahedron 2010, 66, 3165.

11. Li, J.; Mi, Y.; He, J.; Deng, X. Synlett 2010, 2289.

12. (a) Karanewsky, D. S.; Kishi, Y. J. Org. Chem. 1976, 41, 3026. (b) Fukuyama, T.; Li, T.; Peng, G. Tetrahedron Lett. 1994, 35, 2145.

13. See reference 11 and references there in.

14. Na, Y.; Cha, J.-H.; Yoon, H.-G.; Kwon, Y. Chem. Pharm. Bull. 2009, 57, 607.

15. Yoon, G.; Liu, Z.; Jeong, H. J.; Cheon, S. H. Bull. Korean Chem. Soc. 2009, 30, 2959.

16. Polshettiwar, V.; Varma, R. Acc. Chem. Res. 2008, 41, 629.

17. Rideout, D. C.; Moritra, U.; Breslow, R. Tetrahedron Lett. 1983, 24, 1901.

18. Portmann, R. WO Patent 9802423, 1998.

19. Rieber, N.; Alberts, J.; Lipsky, J. A.; Lemal, D. M. J. Am. Chem. Soc. 1969, 91, 5668.

20. Brandes, E.; Grieco, P. A.; Gajewski, J. J. J. Org. Chem. 1989, 54 , 515.

21. Pirrung, M. C.; Das Sarma, K. Tetrahedron 2005, 61, 11456.

22. Finn, M. G. J. Org. Chem. 2004, 69, 7336.

23. Bhattacharya, S.; Sengupta, S. Tetrahedron Lett. 2004, 45, 8733.

24. Churruca, F.; Sanmartin, R.; Tellitu, I.; Dominguez, E. Synlett $\mathbf{2 0 0 5}, 3116$.

25. Jeon, J.-H.; Kim, M. R.; Jun, J.-G. Synthesis 2011, 370.

26. The deprenylation product was inescapable at the high temperature; see Coombers, C. L.; Moody, C. J. J. Org. Chem. 2008, 73, 6758 . 